\title{
フフホト（内モンゴル），上海および大連の 女子大学生の生活習慣の比較
}

\author{
西尾恵里子*·包 阿栄** \\ (*九州共立大学, **内モンゴル大学)
}

(平成27年12月14日受付，平成28年 5 月16日受理）

\section{The comparative study on lifestyle of female university students in Hohhot (Inner Mongolia), Shanghai, and Dalian}

\author{
Eriko Nishio *, Arong Bao**
}

* Kyushu Kyoritsu University, 1-8, Jiyugaoka, Yahatanishi-ku, Kitakyushu-shi, Fukuoka, 807-8585

** Inner Mongolia University, No.235, West College Road, Hohhot, Inner Mongolia, 010021, China

*\% 807-8585 福岡県北九州市八幡西区自由ケ丘 1-8

**010021 中華人民共和国内モンゴル自治区呼和浩特市大学西路235号

With its large population, the prospect of an aging society have recently been identified as a major concern in China. We considered that the lifestyle of university students influences their health during their school years and later in life. An anonymous questionnaire was conducted, aimed at providing an understanding of the lifestyles and self-esteem levels of university students. It was administered between March and July 2015, to 406 female Chinese university students in three Chinese communities. These included 150 students in Hohhot (Inner Mongolia), 175 in Shanghai, and 81 in Dalian.

Overall, it was a desirable lifestyle to have few students who consumed alcohol and smoked. However, 32.8\% (133/406) of the students were underweight (BMI < 18.5), $21.9 \%(89 / 406)$ exercised, and $45.1 \%(183 / 406)$ used the Internet for more than three hours a day.

The Rosenberg Self-Esteem Scale (RSES) score of the 406 students was $29.14 \pm$ 4.04. A residual analysis revealed that a significantly greater number of Hohhot students gave first preference to the university than did the Shanghai students. The RSES score of the Hohhot students was lower than that of the Shanghai students.

In total, $21.9 \%(89 / 406)$ of the students in Hohhot, Shanghai, and Darian had exercise habits, while 10.0\% (15/150) of the students in Hohhot and 34.3\% (60/175) in Shanghai exercised.

Overall, 53.7\% (218/406) of the students in the three communities belonged to afterschool activities, while 41.3\% (62/150) of the students in Hohhot and 64.0\% (112/175) in Shanghai were involved in such activities. The analysis also showed that the Hohhot and Shanghai students' performance was significantly lower and higher respectively, in exercise habits and after-school activities.

Overall, 14.5\% (59/406) of the students had part-time work, while 10.0\% (15/150), $22.9 \%(40 / 175)$, and $4.9 \%(4 / 81)$ of the students in Hohhot, Shanghai and Dalian worked, respectively. Dalian had the fewest students doing part-time work. 


\section{1. 緒言}

中国は2009年に日本を追い越し，名目 GDP（国内総 生産）が世界第 2 位となった ${ }^{1)}$ 。アジアインフラ投資銀 行の設立や日本での中国人観光客の爆買いなど，経済成 長の著しい中国に関する記事を近年よく目にするように なった。目覚しい経済発展の一方で，日本と同様にこれ からの少子高齢化の進展が問題となってくる。日本にお ける65歳以上の高齢者は 2014 年の時点で 3,300 万人で,

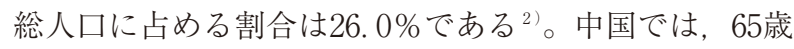
以上の高齢者は 2010 年の時点で 1 億 1 千万人で, 総人口 に占める割合は $8.2 \%$ であ。2020年には 1 億 7 千万人 となり総人口に占める割合は $12.1 \%, 2040$ 年には 3 億 4 千万人となり総人口に占める割合は $24.6 \%$ と予測されて いる ${ }^{3)}$ 。中国では総人口に占める高齢者の割合は日本ほ ど大きくないものの，高齢者人口の規模の大きさや経済 発展の途中で急速に進んだ高齢化により，介護や年金問 題に直面しているとの指摘もある ${ }^{4)}$ 。したがって，医療 費の増大抑制, 労働力人口確保, 介護支援の強化などが やがて避けられなくなるであろうことから, 生活習慣を 改善して健康寿命を延ばすことが重要課題となってくる。

ところで, 中国の大学進学率は2002年に $15.0 \%$ となっ た ${ }^{5)}$ 。マス型の時代に入ったこともあり, 大学生の生活 習慣に関する研究が行われるようになってきている ${ }^{6-10)}$ 。 筆者らは，大学時代の生活習慣の質が，その後の彼らの 健康状態に影響を及ぼすのではないかと考えている。照 屋 ${ }^{11)}$ は，健康になるための力として「健康力」を掲げ, 教育現場で「学力」「体力」とともに「健康力」を育成 することの重要性を述べている。

同じアジア圏という近い国にありながら，われわれは 中国人の生活習慣を知る機会があまりなかった。今回, 中国の 3 地域にある大学に所属する学生の生活習慣に関 するアンケート調査を行う機会を得た。すなわち内モン ゴルのフフホトにある A大学 150 人, 上海にある B 大学 175 人，大連にある C 大学 81 人の女子学生を対象として, 自尊感情, 体型, 食事および嗜好品の摂取状況をはじめ, 居住形態, 睡眠習慣, 運動習慣, 課外活動状況を把握す るための調査を行った。そして，大学別にそれらの調査 データを集計し解析することにより，中国における女子 大学生の健康習慣の実態把握を試みた。

\section{2. 方 法}

\section{(1) 対象者の概要}

中国は，22省・ 5 自治区・ 4 直轄市 · 2 特別行政区に 分けられ, 合計33の一級行政区が存在する。内モンゴル 自治区，上海市および遼寧省の面積 ${ }^{12-14)}$ ，2012年の時点 での人口，地区総生産額ならびに住民消費水準 ${ }^{15)}$ を表 1 に示す。

内モンゴル自治区フフホト市の $\mathrm{A}$ 大学, 上海市の $\mathrm{B}$ 大学, 遼寧省大連市の C 大学に所属する中国人学生を
対象に，平成27年 3 月から 7 月にかけて，質問票による アンケート調査を行った。有効回答率および有効者の人 数は, A 大学が $82.9 \%, 175$ 人（男子 25 人，女子 150 人), B 大学が $79.6 \%, 223$ 人（男子 48 人, 女子 175 人), C大 学が $78.6 \%, 121$ 人（男子 40 人，女子 81 人）であった。 いずれの大学も男子学生が少なかったので, 今回は女子 学生, すなわち A 大学 150 人, B 大学 175 人, C 大学 81 人, 合計 406 人の調査内容を取りまとめた。

\section{1 ) 内モンゴル自治区フフホト市の A 大学}

内モンゴル自治区は中国の華北地区に位置し，農業お よび畜産業を主要な産業としている。A大学は首府のフ フホト市内にある。1957年創立の総合大学で, 約100の 国家重点大学のうちの一つである。2014年 9 月の時点で, 在学生は大学院生を含めて約 34,000 人であり, モンゴル 族，ダフール族，オウンク族や回族などの少数民族が 3 分の 1 を占めている。今回の調査では, 外国語学部の女 子学生 1 年 47 人 $(31.3 \%), 2$ 年 47 人 $(31.3 \%), 3$ 年 55 人 $(36.7 \%), 4$ 年 1 人 $(0.7 \%)$, 合計 150 人を対象者と した。

\section{2 ）上海市の B 大学}

国の直轄市である上海市は, 中国華東地区に位置し, 商業，金融，工業，交通などの中枢都市である。 B 大学 は上海市内にあり，1951年創立の工学部を主とした大学 で, 在学生は約 1 万人である。今回の調査では, 外国語 学部の女子学生 1 年 41 人 $(23.4 \%), 2$ 年 48 人 $(27.4 \%)$, 3 年 80 人 $(45.7 \%), 4$ 年 6 人 $(3.4 \%)$, 合計 175 人を対 象者とした。

\section{3 ）遼寧省大連市の C 大学}

遼寧省は中国東北地区に位置する省で, C 大学は遼寧 省南部の大連市内にある。大連市の主要産業は, 石油化 学, 電子情報・ソフトウェア, 造船などである。C大学 は1964年創立の外国語大学であり, 在学生は大学院生を 含めて約 15,000 人である。今回の調査では, 情報学およ び外国語を学んでいる情報系学部の女子学生 1 年 47 人 $(58.0 \%), 2$ 年 17 人 $(21.0 \%) ， 3$ 年 16 人 $(19.8 \%), 4$ 年 1 人 $(1.2 \%)$, 合計 81 人を対象者とした。

\section{（2）調査内容および解析方法}

調査内容は，属性，自尊感情，身長および体重，食事 および嗜好品の摂取状況，生活習慣，健康意識，学習意 欲である。属性の調査項目は, (1)民族, (2)今の大学は第 一志望で入学したかどうかとした。

自尊感情の評価には, Rosenberg 自尊感情尺度日本語 版に記されている10項目 ${ }^{16)}$ を用いた（表 2 )。すなわち, 「強くそう思う（4 点)」, 「そう思う（3 点)」, 「そう思わ ない（2 点)」, 「強くそう思わない（1 点)」の 4 段階で 評価した。ただし，表 2 の項目 $2 ， 5 ， 6 ， 8 ， 9$ の逆 転項目については, 項目の 4 点を該当する逆転項目の 1 点， 3 点を 2 点， 2 点を 3 点， 1 点を 4 点にそれぞれ換 算して評価した。 3 大学の Cronbach の $\alpha$ 係数は 0.729

$120(36)$ 
フフホト (内モンゴル), 上海抢よび大連の女子大学生の生活習慣の比較

表 13 地域の面積，人口，地区総生産額および住民消費水準

\begin{tabular}{|c|c|c|c|}
\hline 項 目 & 内モンゴル & 上海 & 遼寧 \\
\hline 面積 $\left(\mathrm{km}^{2}\right)$ & 118. 3万 & $6,340.5$ & 14.8 万 \\
\hline 人口（人）（2012年） & 2, 490万 & 2,380 万 & 4,389 万 \\
\hline 地区総生産額（元）（2012年） & 1 兆 5,881 億 & 2 兆182億 & 2 兆 4,846 億 \\
\hline 住民消費水準（元 / 人·年）（2012年） & $15,195.5$ & $36,892.9$ & $17,998.7$ \\
\hline
\end{tabular}

資料：中国統計年鑑 2013年版および 3 地域のホームページ（内蒙古自治区人民政府；http://www.nmg.gov.cn/, 中国上海；http://www.shanghai.gov.cn/，遼寧省人民政府；http://www.ln.gov.cn/）

\section{表 2 自尊感情尺度の各項目}

\begin{tabular}{l} 
項 目 \\
\hline 1. 私は, 自分自身にだいたい満足している。 \\
2. 時々, 自分は全くダメだと思うことがある。 \\
3. 私にはけっこう長所があると感じている。 \\
4. 私は, 他の大半の人と同じくらいに物事がこなせる。 \\
5. 私には誇れるものが大してないと感じる。 \\
6. 時々, 自分は役に立たないと強く感じることがある。 \\
7. 自分は少なくとも他の人と同じくらい価值のある人間た \\
と感じている。 \\
8. 自分のことをもう少し尊敬できたらいいと思う。 \\
9. よく, 私は落ちこぼれだと思ってしまう。 \\
10. 私は, 自分のことを前向きに考えている。 \\
\hline
\end{tabular}

であり，信頼性の高い尺度 ${ }^{17)}$ とみなされた。自己申告し てもらった身長および体重から，BMI〔体重 $(\mathrm{kg}) /$ 身 長 $(\mathrm{m})^{2}$ ]を算出した。

食事および嗜好品の摂取状況の調査項目は，(1)食事時 間の規則性，(2)朝食の摂取頻度，(3)昼食の摂取頻度，(4) 夕食の捸取頻度, (5)夜食の摂取頻度, (6)喫煙の有無, (7) 飲酒の頻度，8拈菓子の摂取頻度，97ァストフードの 摂取頻度, 10主食としている物, 11最もよく飲む飲料物 とした。

生活習慣の調査項目は，(1)居住形態，(2)起床時刻（平 日), (3)就寝時刻 (平日), (4)睡眠時間（平日)，(5)睡眠 の質, (6)就寝時刻の規則性, (7)運動習慣, 8)クラ゙, サー クル活動などの課外活動の実施状況，9アルバイトの実 施状況，(10) 1 日のインターネット使用時間とした。(5)の 睡眠の質の評価には, 平成22年国民健康 ·栄養調査 ${ }^{18)}$ の 質問項目，「この 1 か月に，寝つきが悪い，途中で目が 覚める，熟睡できないなど眠れないことがありますか」 を用いた。(7)の運動習慣については, 平成22年国民健康 · 栄養調査 ${ }^{18)}$ の「運動習慣のある者は，1回30分以上の運 動を週 2 日以上実施し， 1 年以上継続している者」を基 準として用いた。

健康意識の調査項目は，「自分の健康状態についてと う思うか」とした。学習意欲の項目は，「学習意欲があ るかどうか」とした。

調査結果については，大学別に集計を行った。その際 の統計解析には IBM SPSS Ver.23（日本 IBM 株式会社） を用いた。自尊感情尺度の得点, 身長, 体重および BMI は平均值 標準偏差で示し, 一元配置分散分析な
らびに多重比較（Bonferroni 検定）を行った。その他の 項目については， $\chi^{2}$ 検定を行った。有意差が示された 場合は，カテゴリーを特定化するため残差分析を行い， 調整済み残差を求めた。 5 \%水準未満を有意とした。

\section{（3）倫理的配慮}

本調査の実施にあたっては，九州共立大学倫理審査委 員会の承認を得た（承認番号：2014-07）。

\section{3. 結果}

（1）属性

3 大学間での属性の比較結果を表 3 に示す。A大学は 約半数が漢民族，約 $40 \%$ がモンゴル族，B 大学は大半が 漢民族，C 大学は約 $85 \%$ が漢民族，約 $15 \%$ がその他の民 族であった。大学に第一志望で入学した者は A大学が 有意に多く，B 大学が有意に少なかった。

\section{（2）自尊感情尺度の得点，身長，体重および BMI}

自尊感情尺度の得点，身長，体重および BMI の平均 值を 3 大学で比較した結果が表 4 である。A 大学の自尊 感情尺度の得点は B 大学と比べて有意に低かった。

身長，体重およびBMI の 3 大学全体の平均值は，そ

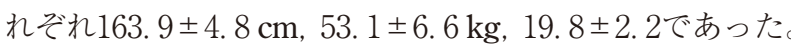
体重およびBMI は大学間で有意差がみられた。BMIが 18.5 未満の者は, $\mathrm{A}$ 大学 29 人 $(19.3 \%), \mathrm{B}$ 大学 82 人 $(46.9 \%), \mathrm{C}$ 大学 22 人 $(27.2 \%), 3$ 大学全体で 133 人 (32.8\%) であった。BMI 25 以上の者は, A大学 7 人 $(4.7 \%), B$ 大学 3 人 $(1.7 \%), \mathrm{C}$ 大学 2 人 $(2.5 \%)$, 3 大学全体で 12 人 (3.0\%) であった。BMI 30以上の者 はどの大学にもいなかった。

\section{（3）食事と嗜好品の摂取状況}

食事と嗜好品の摂取状況について 3 大学間で比較した 結果を，表 5 に示す。食事時間は, “たまに不規則”が どの大学でも約半数を占めており, 大学間での有意差は なかった。

朝食を週 6〜 7 日摂る者の割合は 3 大学全体で約 $60 \%$, 昼食を週 6〜 7 日摂る者の割合は約80\%, 夕食を週 6〜 7 日摂る者の割合は約50\%，夜食を週 0 ～ 1 日摂る者の 割合は約70\%であった。残差分析により，A大学では朝 食をほぼ毎日摂る者が有意に少なく，昼食をほぼ毎日摂 
日本食生活学会誌 Vol.27 No.2（2016）

表 33 大学間での属性の比較

\begin{tabular}{|c|c|c|c|c|c|c|c|c|c|}
\hline \multirow{2}{*}{ 項 目 } & \multirow{2}{*}{ カテゴリ } & \multirow{2}{*}{$\begin{array}{c}\text { 全体 }(n=406) \\
n(\%)\end{array}$} & \multicolumn{2}{|c|}{ A大学 $(n=150)$} & \multicolumn{2}{|c|}{$\mathrm{B}$ 大学 $(n=175)$} & \multicolumn{2}{|c|}{ C大学 $(n=81)$} & \multirow{2}{*}{ 大学間差 $p$} \\
\hline & & & $n(\%)$ & 残差 & $n(\%)$ & 残差 & $n(\%)$ & 残差 & \\
\hline \multirow{3}{*}{ (1)民族 } & 1. 漢民族 & $319(78.6)$ & $78(52.0)$ & $-10.0^{+\dagger \dagger}$ & $172(98.3)$ & $8.4^{\dagger+\dagger}$ & $69(85.2)$ & 1.6 & \multirow{3}{*}{$<0.001^{* * *}$} \\
\hline & 2. モンゴル族 & $64(15.8)$ & $62(41.3)$ & $10.8^{\dagger+\dagger}$ & $1 \quad(0.6)$ & $-7.3^{\dagger+\dagger}$ & $1 \quad(1.2)$ & $-4.0^{\dagger+\dagger}$ & \\
\hline & 3. その他 & $23 \quad(5.7)$ & $10 \quad(6.7)$ & 0.7 & $2 \quad(1.1)$ & $-3.4^{\dagger \dagger \dagger}$ & $11(13.6)$ & $3.4^{\dagger+\dagger}$ & \\
\hline \multirow{2}{*}{$\begin{array}{l}\text { (2)今の大学は第一志望 } \\
\text { ですか }\end{array}$} & 1.はい & $200(49.3)$ & $119(79.3)$ & $9.3^{\dagger+\dagger}$ & $47(26.9)$ & $-7.9^{\dagger \dagger \dagger}$ & $34(42.0)$ & -1.5 & \multirow{2}{*}{$<0.001^{* * *}$} \\
\hline & 2.いいえ & $206(50.7)$ & $31(20.7)$ & $-9.3^{\dagger+\dagger}$ & $128(73.1)$ & 7. $9^{\dagger+\dagger}$ & $47(58.0)$ & 1.5 & \\
\hline
\end{tabular}

$\chi^{2}$ 検定: **** $p<0.001$

残差分析: ${ }^{\dagger \dagger} p<0.001$

表 43 大学間での自尊感情尺度の得点, 身長, 体重および BMI の比較

\begin{tabular}{|c|c|c|c|c|c|c|}
\hline & $\begin{array}{c}\text { 全体 } \\
n=406 \\
\text { 平均土標準偏差 }\end{array}$ & $\begin{array}{c}\mathrm{A} \text { 大学 } \\
n=150 \\
\text { 平均土標準偏差 }\end{array}$ & $\begin{array}{c}\mathrm{B} \text { 大学 } \\
n=175 \\
\text { 平均土標準偏差 }\end{array}$ & $\begin{array}{c}\mathrm{C} \text { 大学 } \\
n=81 \\
\text { 平均 } \pm \text { 標準偏差 }\end{array}$ & $\begin{array}{c}\text { 大学間差 } \\
p\end{array}$ & 多重比較 \\
\hline 自尊感情尺度の得点 & 29. $14 \pm 4.04$ & $28.40 \pm 3.76$ & $29.77 \pm 4.28$ & $29.14 \pm 3.84$ & $0.009^{* *}$ & $A \& B$ \\
\hline 身長（cm） & $163.9 \pm 4.8$ & $163.3 \pm 4.9$ & $164.0 \pm 4.5$ & $164.6 \pm 5.1$ & 0.12 & - \\
\hline 体重（kg） & $53.1 \pm 6.6$ & $54.3 \pm 6.7$ & $51.7 \pm 6.1$ & $53.8 \pm 6.9$ & $0.001^{* *}$ & $A \& B, \quad B \& C$ \\
\hline BMI & $19.8 \pm 2.2$ & $20.4 \pm 2.2$ & $19.2 \pm 2.0$ & $19.8 \pm 2.2$ & $<0.001^{* * *}$ & $A \& B$ \\
\hline
\end{tabular}

ANOVA 検定: **** $p<0.001,{ }^{* * *} p<0.01$

Bonferroni による多重比較で有意差が認められた群の組み合わせ (A：A大学, B：B大学, C ：C大学)

表 53 大学間での食事および嗜好品の摂取状況の比較

\begin{tabular}{|c|c|c|c|c|c|c|c|c|c|c|c|}
\hline \multirow[t]{2}{*}{ 項 目 } & \multirow[t]{2}{*}{ カテゴリ } & \multirow{2}{*}{$\begin{array}{c}\text { 全体 } \\
(n=406) \\
n(\%)\end{array}$} & \multicolumn{2}{|c|}{ A大学 $(n=150)$} & \multicolumn{3}{|c|}{ B 大学 $(n=175)$} & \multicolumn{3}{|c|}{ C 大学 $(n=81)$} & \multirow{2}{*}{$\begin{array}{c}\text { 大学間差 } \\
p \\
\end{array}$} \\
\hline & & & $n(\%)$ & 残差 & $n$ & $(\%)$ & 残差 & $n$ & $(\%)$ & 残差 & \\
\hline \multirow{3}{*}{ (1)食事時間の規則性 } & 1. ほぼ毎日規則的 & $139(34.2)$ & $54(36.0)$ & - & 55 & $(31.4)$ & - & 30 & $(37.0)$ & - & \multirow{3}{*}{0.39} \\
\hline & 2. たまに不規則 & $221(54.4)$ & $83(55.3)$ & - & 94 & $(53.7)$ & - & 44 & $(54.3)$ & - & \\
\hline & 3. 不規則なことが多い & $46(11.3)$ & $13 \quad(8.7)$ & - & 26 & $(14.9)$ & - & 7 & $(8.6)$ & - & \\
\hline \multirow{4}{*}{ (2)朝食 } & 1. 週 $6 \sim 7$ 日摂る & $250(61.6)$ & $74(49.3)$ & $-3.9^{\dagger \dagger \dagger}$ & 119 & $(68.0)$ & $2.3^{\dagger}$ & 57 & $(70.4)$ & 1.8 & \multirow{4}{*}{$<0.001^{* * *}$} \\
\hline & 2. 週 $4 \sim 5$ 日摂る & $119(29.3)$ & $51(34.0)$ & 1.6 & 51 & $(29.1)$ & -0.1 & 17 & $(21.0)$ & -1.8 & \\
\hline & 3. 週 $2 \sim 3$ 日摂る & $19 \quad(4.7)$ & $13 \quad(8.7)$ & $2.9^{\dagger \dagger}$ & 3 & $(1.7)$ & $-2.5^{\dagger}$ & 3 & $(3.7)$ & -0.5 & \\
\hline & 4. 週 0 〜 1 日摂る & $18 \quad(4.4)$ & $12 \quad(8.0)$ & $2.7^{\dagger \dagger}$ & 2 & $(1.1)$ & $-2.8^{\dagger \dagger}$ & 4 & $(4.9)$ & 0.2 & \\
\hline \multirow{3}{*}{ (3)昼食 } & 1. 週 $6 \sim 7$ 日摂る & $319(78.6)$ & $128(85.3)$ & $2.5^{\dagger}$ & 122 & $(69.7)$ & $-3.8^{\dagger \dagger \dagger}$ & 69 & $(85.2)$ & 1.6 & \multirow{3}{*}{$<0.001^{* * *}$} \\
\hline & 2. 週 4〜 5 日摂る & $66(16.3)$ & $13 \quad(8.7)$ & $-3.2^{\dagger \dagger}$ & 45 & $(25.7)$ & $4.5^{\dagger \dagger \dagger}$ & 8 & $(9.9)$ & -1.7 & \\
\hline & 3. 週 0 〜 3 日摂る & $21 \quad(5.2)$ & $9 \quad(6.0)$ & 0.6 & 8 & $(4.6)$ & -0.5 & 4 & $(4.9)$ & -0.1 & \\
\hline \multirow{4}{*}{ (4)夕食 } & 1. 週 $6 \sim 7$ 日摂る & $209(51.5)$ & $81 \quad(54.0)$ & 0.8 & 92 & $(52.6)$ & 0.4 & 36 & $(44.4)$ & -1.4 & \multirow{4}{*}{$0.005^{* * *}$} \\
\hline & 2. 週 4 〜 5 日摂る & $71(17.5)$ & $30(20.0)$ & 1.0 & 18 & $(10.3)$ & $-3.3^{\dagger \dagger}$ & 23 & $(28.4)$ & $2.9^{\dagger \dagger}$ & \\
\hline & 3. 週 $2 \sim 3$ 日摂る & $86(21.2)$ & $26(17.3)$ & -1.5 & 48 & $(27.4)$ & $2.7^{\dagger \dagger}$ & 12 & $(14.8)$ & -1.6 & \\
\hline & 4. 週 $0 \sim 1$ 日摂る & $40 \quad(9.9)$ & $13 \quad(8.7)$ & -0.6 & 17 & $(9.7)$ & -0.1 & 10 & (12.3) & 0.8 & \\
\hline \multirow{4}{*}{ (5)夜食 } & 1. 週 $6 \sim 7$ 日摂る & $17 \quad(4.2)$ & $1 \quad(0.7)$ & $-2.7^{\dagger \dagger}$ & 12 & $(6.9)$ & $2.3^{\dagger}$ & 4 & $(4.9)$ & 0.4 & \multirow{4}{*}{$0.017^{*}$} \\
\hline & 2. 週 4 〜 5 日摂る & $17 \quad(4.2)$ & $4 \quad(2.7)$ & -1.2 & 11 & (6.3) & 1.8 & 2 & $(2.5)$ & -0.9 & \\
\hline & 3. 週 2〜3 日摄る & $76(18.7)$ & $23(15.3)$ & -1.3 & 38 & $(21.7)$ & 1.3 & 15 & $(18.5)$ & -0.1 & \\
\hline & 4. 週 $0 \sim 1$ 日摂る & $296(72.9)$ & $122(81.3)$ & $2.9^{\dagger \dagger}$ & 114 & $(65.1)$ & $-3.1^{\dagger \dagger}$ & 60 & $(74.1)$ & 0.3 & \\
\hline \multirow{2}{*}{$\begin{array}{l}\text { (6)たばこ } \\
\text { (ここ1か月間) }\end{array}$} & 1．毎日または時々吸う & $8 \quad(2.0)$ & $4 \quad(2.7)$ & - & 4 & $(2.3)$ & - & 0 & $(0.0)$ & - & \multirow[b]{2}{*}{0.35} \\
\hline & 2. 吸っていない & $398(98.0)$ & $146(97.3)$ & - & 171 & $(97.7)$ & - & 81 & $(100.0)$ & - & \\
\hline \multirow{2}{*}{ (7)飲酒 } & 1. 週 2 日以上飲む & $14 \quad(3.4)$ & $1 \quad(0.7)$ & $-2.4^{\dagger}$ & 10 & $(5.7)$ & $2.2^{\dagger}$ & 3 & $(3.7)$ & 0.1 & \multirow[b]{2}{*}{$0.045^{*}$} \\
\hline & 2. 週 $0 \sim 1$ 日飲む & $392(96.6)$ & $149(99.3)$ & $2.4^{\dagger}$ & 165 & $(94.3)$ & $-2.2^{\dagger}$ & 78 & (96.3) & -0.1 & \\
\hline \multirow{4}{*}{$\begin{array}{l}\text { 8)打菓子（甘い抢菓子, } \\
\text { スナック菓子, せんべ } \\
\text { いなど） }\end{array}$} & 1. 週 6〜 7 日摂る & $42(10.3)$ & $11 \quad(7.3)$ & -1.5 & 25 & $(14.3)$ & $2.3^{\dagger}$ & 6 & $(7.4)$ & -1.0 & \multirow{4}{*}{$0.013^{*}$} \\
\hline & 2. 週 4〜 5 日摂る & $118(29.1)$ & $37(24.7)$ & -1.5 & 63 & $(36.0)$ & $2.7^{\dagger \dagger}$ & 18 & $(22.2)$ & -1.5 & \\
\hline & 3. 週 $2 \sim 3$ 日摂る & $170(41.9)$ & $72(48.0)$ & 1.9 & 59 & $(33.7)$ & $-2.9^{\dagger \dagger}$ & 39 & $(48.1)$ & 1.3 & \\
\hline & 4. 週 0 〜 1 日摂る & $76(18.7)$ & $30(20.0)$ & 0.5 & 28 & $(16.0)$ & -1.2 & 18 & $(22.2)$ & 0.9 & \\
\hline \multirow{3}{*}{$\begin{array}{l}\text { (9)ファストフード（ハン } \\
\text { バーガーなど) }\end{array}$} & 1. 週 4 日以上摂る & $23 \quad(5.7)$ & $1 \quad(0.7)$ & $-3.3^{\dagger \dagger}$ & 18 & $(10.3)$ & $3.5^{\dagger+\dagger}$ & 4 & $(4.9)$ & -0.3 & \\
\hline & 2. 週 2 〜 3 日摂る & $101(24.9)$ & $18(12.0)$ & $-4.6^{\dagger \dagger \dagger}$ & 61 & $(34.9)$ & 4. $0^{\dagger+\dagger}$ & 22 & $(27.2)$ & 0.5 & $<0.001^{* * *}$ \\
\hline & 3. 週 $0 \sim 1$ 日摂る & $282(69.5)$ & $131 \quad(87.3)$ & $6.0^{\dagger \dagger \dagger}$ & 96 & $(54.9)$ & $-5.6^{\dagger+\uparrow}$ & 55 & $(67.9)$ & -0.3 & \\
\hline & 1. 米 & $343(84.5)$ & $130(86.7)$ & - & 147 & $(84.0)$ & - & 66 & $(81.5)$ & - & \\
\hline (10)主食 & 2. 麺類 & $43(10.6)$ & $15(10.0)$ & - & 17 & $(9.7)$ & - & 11 & (13.6) & - & 0.65 \\
\hline & 3. その他 & $20 \quad(4.9)$ & $5 \quad(3.3)$ & - & 11 & (6.3) & - & 4 & $(4.9)$ & - & \\
\hline & 1. 水または白湯 & $283(69.7)$ & $117(78.0)$ & - & 109 & $(62.3)$ & - & 57 & $(70.4)$ & - & \\
\hline & 2．コーヒーまたは茶類（糖分無し） & $37 \quad(9.1)$ & $8 \quad(5.3)$ & - & 21 & $(12.0)$ & - & 8 & $(9.9)$ & - & \\
\hline (11)最もよく飲む飲料 & 3. 缶コーヒー, スポーツドリンクなど糖分あり & $30 \quad(7.4)$ & $11 \quad(7.3)$ & - & 13 & $(7.4)$ & - & 6 & $(7.4)$ & - & 0.14 \\
\hline & 4．野菜ジュースまたは果物ジュース & $46(11.3)$ & $11 \quad(7.3)$ & - & 26 & $(14.9)$ & - & 9 & (11. 1) & - & \\
\hline & 5. その他 & $10 \quad(2.5)$ & $3 \quad(2.0)$ & - & 6 & $(3.4)$ & - & 1 & $(1.2)$ & - & \\
\hline
\end{tabular}

$\chi^{2}$ 検定: ${ }^{* * *} p<0.001,{ }^{* *} p<0.01, \quad * p<0.05$

残差分析 : ${ }^{\dagger \dagger} p<0.001,{ }^{\dagger \dagger} p<0.01,{ }^{\dagger} p<0.05$

$122(38)$ 
フフホト (内モンゴル), 上海抒よび大連の女子大学生の生活習慣の比較

表 63 大学間での生活習慣（居住形態, 睡眠, 運動, 課外活動, アルバイトおよびインターネット使用時間) の比較

\begin{tabular}{|c|c|c|c|c|c|c|c|c|c|c|}
\hline \multirow[t]{2}{*}{ 項 目 } & \multirow[t]{2}{*}{ カテゴリ } & \multirow{2}{*}{$\begin{array}{c}\text { 全体 } \\
(n=406) \\
n(\%)\end{array}$} & \multicolumn{2}{|c|}{ A 大学 $(n=150)$} & \multicolumn{3}{|c|}{ B 大学 $(n=175)$} & \multicolumn{2}{|c|}{ C 大学 $(n=81)$} & \multirow{2}{*}{$\begin{array}{c}\text { 大学間差 } \\
p\end{array}$} \\
\hline & & & $n(\%)$ & 残差 & $n$ & $(\%)$ & 残差 & $n(\%)$ & 残差 & \\
\hline (1)居住形態 & $\begin{array}{l}\text { 1. 寮 } \\
\text { 2. その他 }\end{array}$ & $\begin{array}{rr}394 & (97.0) \\
12 & (3.0)\end{array}$ & $\begin{array}{rr}149 & (99.3) \\
1 & (0.7)\end{array}$ & - & $\begin{array}{r}166 \\
9\end{array}$ & $\begin{array}{r}(94.9) \\
(5.1)\end{array}$ & - & $\begin{array}{rr}79 & (97.5) \\
2 & (2.5)\end{array}$ & - & 0.057 \\
\hline (2)起床時刻（平日） & $\begin{array}{l}\text { 1. 午前 } 7 \text { 時より前 } \\
\text { 2. 午前 } 7 \text { 時〜 } \\
\text { 3. 午前 } 8 \text { 時〜 }\end{array}$ & $\begin{array}{rr}109 & (26.8) \\
279 & (68.7) \\
18 & (4.4) \\
\end{array}$ & $\begin{array}{rr}68 & (45.3) \\
81 & (54.0) \\
1 & (0.7) \\
\end{array}$ & $\begin{array}{r}6.4^{\dagger \dagger \dagger} \\
-4.9^{\dagger \dagger \dagger} \\
-2.8^{\dagger \dagger} \\
\end{array}$ & $\begin{array}{r}17 \\
142 \\
16 \\
\end{array}$ & $\begin{array}{r}(9.7) \\
(81.1) \\
(9.1) \\
\end{array}$ & $\begin{array}{r}-6.8^{\dagger \dagger \dagger} \\
4.7^{\dagger \dagger \dagger} \\
4.0^{\dagger \dagger \dagger}\end{array}$ & $\begin{array}{rr}24 & (29.6) \\
56 & (69.1) \\
1 & (1.2) \\
\end{array}$ & $\begin{array}{r}0.6 \\
0.1 \\
-1.6 \\
\end{array}$ & $<0.001^{* * *}$ \\
\hline (3)就寝時刻（平日） & $\begin{array}{l}\text { 1. 午後10時 } \\
\text { 2. 午後11時 } \\
\text { 3. 午後12時 }\end{array}$ & $\begin{array}{rr}26 & (6.4) \\
237 & (58.4) \\
143 & (35.2) \\
\end{array}$ & $\begin{array}{rr}3 & (2.0) \\
76 & (50.7) \\
71 & (47.3) \\
\end{array}$ & $\begin{array}{l}-2.8^{\dagger \dagger} \\
-2.4^{\dagger} \\
3.9^{\dagger \dagger \dagger}\end{array}$ & $\begin{array}{r}14 \\
105 \\
56 \\
\end{array}$ & $\begin{array}{r}(8.0) \\
(60.0) \\
(32.0) \\
\end{array}$ & $\begin{array}{r}1.1 \\
0.6 \\
-1.2 \\
\end{array}$ & $\begin{array}{rr}9 & (11.1) \\
56 & (69.1) \\
16 & (19.8) \\
\end{array}$ & $\begin{aligned} & 1.9 \\
& 2.2^{\dagger} \\
- & 3.3^{\dagger \dagger}\end{aligned}$ & $<0.001^{* * *}$ \\
\hline (4)睡眠時間（平日） & $\begin{array}{l}\text { 1. } 8 \text { 時間以上 } \\
\text { 2. } 7 \text { 時間以上 } 8 \text { 時間未満 } \\
\text { 3. } 6 \text { 時間以上 } 7 \text { 時間未満 } \\
\text { 4. } 5 \text { 時間以上 } 6 \text { 時間未満 }\end{array}$ & $\begin{array}{rr}40 & (9.9) \\
212 & (52.2) \\
138 & (34.0) \\
16 & (3.9)\end{array}$ & $\begin{array}{rr}8 & (5.3) \\
71 & (47.3) \\
62 & (41.3) \\
9 & (6.0)\end{array}$ & $\begin{aligned}- & 2.3^{\dagger} \\
- & 1.5 \\
& 2.4^{\dagger} \\
& 1.6\end{aligned}$ & $\begin{array}{r}18 \\
98 \\
54 \\
5\end{array}$ & $\begin{array}{l}(10.3) \\
(56.0) \\
(30.9) \\
(2.9)\end{array}$ & $\begin{array}{r}0.3 \\
1.3 \\
-1.2 \\
-1.0\end{array}$ & $\begin{array}{rr}14 & (17.3) \\
43 & (53.1) \\
22 & (27.2) \\
2 & (2.5)\end{array}$ & $\begin{array}{r}2.5^{\dagger} \\
0.2 \\
-1.5 \\
-0.8\end{array}$ & $0.017^{*}$ \\
\hline $\begin{array}{l}\text { (5)この1か月に, 寝つきが悪い, 途中で } \\
\text { 目が覚める, 熟睡できないなど眠れな } \\
\text { いことがありましたか } \\
\end{array}$ & $\begin{array}{l}\text { 1. 頻繁にある } \\
\text { 2. 時々ある } \\
\text { 3. めったにない } \\
\text { 4. 全くない }\end{array}$ & $\begin{array}{rr}19 & (4.7) \\
128 & (31.5) \\
185 & (45.6) \\
74 & (18.2) \\
\end{array}$ & $\begin{array}{lr}11 & (7.3) \\
51 & (34.0) \\
59 & (39.3) \\
29 & (19.3) \\
\end{array}$ & $\begin{array}{r}1.9 \\
0.8 \\
-1.9 \\
0.4 \\
\end{array}$ & $\begin{array}{r}5 \\
49 \\
101 \\
20\end{array}$ & $\begin{array}{l}(2.9) \\
(28.0) \\
(57.7) \\
(11.4) \\
\end{array}$ & $\begin{aligned} &--1.5 \\
&- 1.3 \\
& 4.3^{\dagger+\dagger} \\
&- 3.1^{\dagger \dagger} \\
&\end{aligned}$ & $\begin{array}{rr}3 & (3.7) \\
28 & (34.6) \\
25 & (30.9) \\
25 & (30.9) \\
\end{array}$ & $\begin{array}{r}-0.5 \\
0.7 \\
-3.0^{+\dagger} \\
3.3^{+\dagger} \\
\end{array}$ & $<0.001^{* * * *}$ \\
\hline 〔6就寝時刻の規則性（平日） & $\begin{array}{l}\text { 1. ほぼ毎日正しい } \\
\text { 2. たまに不規則なことがある } \\
\text { 3. 不規則なことが多い }\end{array}$ & $\begin{array}{rr}86 & (21.2) \\
256 & (63.1) \\
64 & (15.8) \\
\end{array}$ & $\begin{array}{rr}29 & (19.3) \\
101 & (67.3) \\
20 & (13.3) \\
\end{array}$ & $\begin{array}{l}- \\
- \\
\end{array}$ & $\begin{array}{r}38 \\
103 \\
34 \\
\end{array}$ & $\begin{array}{l}(21.7) \\
(58.9) \\
(19.4) \\
\end{array}$ & $\begin{array}{l}- \\
- \\
\end{array}$ & $\begin{array}{ll}19 & (23.5) \\
52 & (64.2) \\
10 & (12.3)\end{array}$ & $\begin{array}{l}- \\
- \\
-\end{array}$ & 0.40 \\
\hline $\begin{array}{l}\text { (7) } 1 \text { 回30分以上の運動を週 } 2 \text { 日以上実施 } \\
\text { し, } 1 \text { 年以上継続していますか (授業 } \\
\text { を除く) }\end{array}$ & $\begin{array}{l}\text { 1. はい } \\
\text { 2. いいえ }\end{array}$ & $\begin{array}{r}89(21.9) \\
317(78.1)\end{array}$ & $\begin{array}{r}15(10.0) \\
135(90.0)\end{array}$ & $\begin{array}{r}-4.4^{\dagger \dagger \dagger} \\
4.4^{\dagger \dagger \dagger}\end{array}$ & $\begin{array}{r}60 \\
115 \\
\end{array}$ & $\begin{array}{l}(34.3) \\
(65.7)\end{array}$ & $\begin{array}{r}5.2^{\dagger \dagger \dagger} \\
-5.2^{\dagger \dagger \dagger} \\
\end{array}$ & $\begin{array}{l}14(17.3) \\
67(82.7)\end{array}$ & $\begin{array}{r}-1.1 \\
1.1\end{array}$ & $<0.001^{* * *}$ \\
\hline $\begin{array}{l}\text { 8)クラブ, サークル活動などの課外活動 } \\
\text { の実施状況 } \\
\end{array}$ & $\begin{array}{l}\text { 1. している } \\
\text { 2. していない }\end{array}$ & $\begin{array}{l}218(53.7) \\
188(46.3) \\
\end{array}$ & $\begin{array}{ll}62 & (41.3) \\
88 & (58.7) \\
\end{array}$ & $\begin{array}{r}-3.8^{\dagger \dagger \dagger} \\
3.8^{\dagger \dagger \dagger} \\
\end{array}$ & $\begin{array}{r}112 \\
63 \\
\end{array}$ & $\begin{array}{l}(64.0) \\
(36.0) \\
\end{array}$ & $\begin{array}{r}3.6^{\dagger \dagger \dagger} \\
-3.6^{\dagger \dagger \dagger} \\
\end{array}$ & $\begin{array}{l}44(54.3) \\
37(45.7) \\
\end{array}$ & $\begin{array}{r}0.1 \\
-0.1 \\
\end{array}$ & $<0.001^{* * * *}$ \\
\hline (9)ルバイトの実施状況 & $\begin{array}{l}\text { 1. している } \\
\text { 2. していない }\end{array}$ & $\begin{array}{rr}59 & (14.5) \\
347 & (85.5) \\
\end{array}$ & $\begin{array}{r}15(10.0) \\
135(90.0) \\
\end{array}$ & $\begin{array}{r}-2.0^{\dagger} \\
2.0^{\dagger} \\
\end{array}$ & $\begin{array}{r}40 \\
135 \\
\end{array}$ & $\begin{array}{l}(22.9) \\
(77.1)\end{array}$ & $\begin{array}{r}4.1^{\dagger \dagger \dagger} \\
-4.1^{\dagger \dagger \dagger} \\
\end{array}$ & $\begin{array}{rr}4 & (4.9) \\
77 & (95.1) \\
\end{array}$ & $\begin{array}{r}-2.7^{\dagger \dagger} \\
2.7^{\dagger \dagger} \\
\end{array}$ & $<0.001^{* * *}$ \\
\hline $\begin{array}{l}\text { (10)毎日平均して何時間インターネットを } \\
\text { していますか（メール，LINEも含む） }\end{array}$ & $\begin{array}{ll}\text { 1. } 1 \text { 時間以内 } \\
\text { 2. } 2 \text { 時間以内 } \\
\text { 3. } 3 \text { 時間以内 } \\
\text { 4. } 3 \text { 時間以上 }\end{array}$ & $\begin{array}{rr}34 & (8.4) \\
90 & (22.2) \\
99 & (24.4) \\
183 & (45.1) \\
\end{array}$ & $\begin{array}{ll}11 & (7.3) \\
46 & (30.7) \\
44 & (29.3) \\
49 & (32.7) \\
\end{array}$ & $\begin{aligned} &- 0.6 \\
& 3.2^{\dagger \dagger} \\
& 1.8 \\
&- 3.8^{\dagger \dagger \dagger} \\
&\end{aligned}$ & $\begin{array}{l}12 \\
28 \\
45 \\
90 \\
\end{array}$ & $\begin{array}{l}(6.9) \\
(16.0) \\
(25.7) \\
(51.4) \\
\end{array}$ & $\begin{aligned} &- 1.0 \\
&- 2.6^{\dagger \dagger} \\
& 0.5 \\
& 2.2^{\dagger}\end{aligned}$ & $\begin{array}{ll}11 & (13.6) \\
16 & (19.8) \\
10 & (12.3) \\
44 & (54.3) \\
\end{array}$ & $\begin{array}{r}1.9 \\
-0.6 \\
-2.8^{\dagger \dagger} \\
1.9 \\
\end{array}$ & $<0.001^{* * *}$ \\
\hline
\end{tabular}

$\chi^{2}$ 検定: ${ }^{* * *} p<0.001,{ }^{*} p<0.05$

残差分析 : ${ }^{\dagger \dagger} p<0.001,{ }^{\dagger \dagger} p<0.01,{ }^{\dagger} p<0.05$

る者が有意に多く，夜食を摂っていない者が有意に多 かった。 B 大学では朝食をほぼ毎日摂る者が有意に多く, 昼食をほぼ毎日摂る者が有意に少なかった。

“タバコを吸っていない”者の割合は 3 大学全体で 98. 0\%であり, 大学間での有意差はなかった。同様に, “扮 酒を週 0 ～ 1 日飲む”者の割合は 3 大学全体で $96.6 \%$ で あり、ほとんどの者が飲んでいなかった。次に、“㨐菓 子を週 4 日以上摂る”者の割合は 3 大学全体で $39.4 \%$,

B 大学で $50.3 \%$ であった。“ファストフードを週 2 日以 上摂る”者の割合は 3 大学全体で $30.6 \%, \mathrm{~B}$ 大学で 45. $2 \%$ であった。B大学では拉菓子とファストフードを よく摄取していた。

主食を“米”とする者の割合は， 3 大学全体で $84.5 \%$ であり，大学間での有意差はなかった。最もよく飲む飲 料を“水または白湯”とする者の割合は 3 大学全体で 69.7\%, 次いで“野菜ジュースまたは果物ジュース”が 11.3\%であり, 大学間での有意差はなかった。

\section{（4）生活習慣}

生活習慣の状態を 3 大学間で比較した（表 6 ）。寮に 住んでいる者の割合は，3 大学全体で $97.0 \%$ あり，大 学間での有意差はなかった。
午前 7 時〜 8 時の間に起床する者の割合は， 3 大学全 体で約70\%であった。午前 7 時より前に起床している者 が A大学では68人 (45.3\%) で有意に多く, 午前 7 時 〜 8 時の間に起床している者が B 大学では 142 人 （81.1\%）で有意に多かった。午後12時以降に就寝する 者の割合は 3 大学全体で約 $35 \%$ であり，A大学では 71 人 (47.3\%) で有意に多く，C大学では16人 (19.8\%) で 有意に少なかった。また, 3 大学全体で $52.2 \%$ 者が, 平日 7 時間以上 8 時間未満の睡眠をとっていた。さらに, $\mathrm{A}$ 大学では睡眠時間が短く C 大学では睡眠時間が長い ことがわかった。睡眠の質は B 大学掞よびC大学が良 好であった。平日の就寝時刻の規則性については, “た まに不規則なことがある”が 3 大学全体で63.1\%であり， 大学間での有意差はなかった。

運動習慣がある者の割合は 3 大学全体で 89 人 (21.9\%) であり，A大学では 15 人 (10.0\%) で有意に少なく, B 大学では60人 (34.3\%) で有意に多かった。クラブ, サー クル活動などの課外活動をしている者の割合は 3 大学全 体で218人 (53.7\%) であり，A大学では62人 (41.3\%) で有意に少なく，B大学では 112 人 (64.0\%) で有意に 多かった。アルバイトをしている者の割合は，3大学全 体で59人 (14.5\%) であり, C大学では 4 人 (4.9\%) 


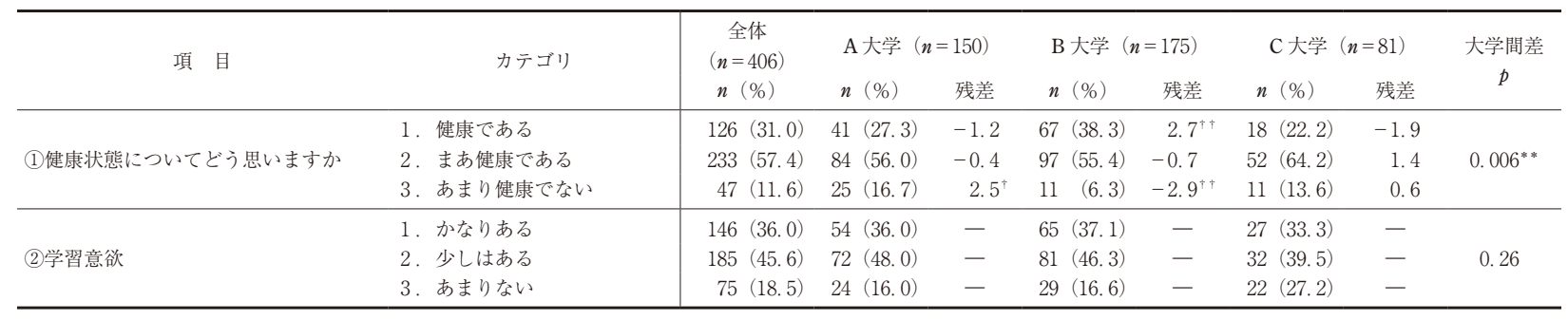

$\chi^{2}$ 検定: *** $p<0.01$

残差分析: ${ }^{\dagger \dagger} p<0.01,{ }^{\dagger} p<0.05$

で最も少なかった。夜10時以降にアルバイトをしている 者は，3 大学全体でわずか 4 人 (1.0\%) と少なかった。 毎日 3 時間以上インターネットをしている者の割合は 3 大学全体で 183 人 $(45.1 \%)$ であり，A大学では 49 人 （32.7\%）で有意に少なかった。

\section{（５）健康意識および学習意欲}

健康意識および学習意欲を 3 大学で比較した結果を表 7 に示す。健康意識については，3 大学全体で約 $60 \%$ の 者が“まあ健康である”としていた。なお，A大学には “あまり健康でない”と思う者が有意に多く，B大学で は有意に少なかった。

学習意欲については, “かなりある”と思う者の割合

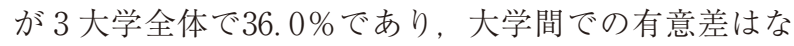
かった。

\section{4. 考察}

内モンゴルフフホト市の A 大学, 上海市の B 大学, 遼寧省大連市の C 大学の女子学生について, 自尊感情, 体型，食事および嗜好品の摂取状況，居住形態，睡眠習 慣，運動習慣および課外活動状況を調查した。

中国は，90年代初めから市場経済を本格的に導入して おり，それに伴うテレビ，雑誌，新聞広告などの影響に より，若い女性の間で「瘦せ」が好まれるようになっ た ${ }^{19)}$ 。日本では, 平成25年における20歳代女性の低体重 者（BMI 18.5 未満の者）の割合は21.5\%と高く ${ }^{20)}$, 若 い女性の「瘦せ」が問題となっている。 3 大学における 低体重者の人数は, A 大学 29 人 $(19.3 \%), \mathrm{B}$ 大学 82 人 $(46.9 \%), \mathrm{C}$ 大学 22 人 $(27.2 \%), 3$ 大学全体で 133 人 (32.8\%) であり，B大学で顕著に多い状態にあった。 Sakamaki $^{6)}$ らは, 中国の北京および昆明の男女の大学 生540人を対象とした食習慣や体型認知などに関するア ンケート調査結果から, 女子学生は男子学生よりも瘦せ の願望があることを指摘している。これらから，今回の 調査結果には女子学生の瘦せ願望が反映しているものと 思われる。

Rosenberg 自尊感情尺度の評定值は，3 大学平均で 29.14 4 4.04であった（表 4 ）。日本人男女学生の評定平 均值が約25であること ${ }^{16,21,22)}$ を考えると, 中国の大学生
は高い状態といえる。A大学ではこの大学を第一志望と する者が 119 人 $(79.3 \%)$ で有意に多く，B大学では 47 人 (26.9\%) で有意に少なかった（表 3 (2)）が，自尊感 情尺度の評定值は A大学が $\mathrm{B}$ 大学に比べて有意に低かっ た（表 4)。学習意欲については, 3 大学間で差はなく, 意欲のある者は 3 大学平均で $36.0 \%$ あった（表 7 (2)）。 なお，自尊感情尺度の評定值に影響を及ぼす要因につい ては，次報で報告する予定である。

A 大学では課外活動をしている者および運動習慣のあ

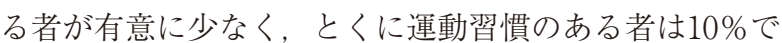
あった（表 6 (7)，8）。A 大学が重点大学の一つである ことを考慮すると, 白 ${ }^{23)}$ が中国の学校外教育での問題点 としてあげている「中国では，頭脳を使う人には手を使 わせないように教育している」との路線の影響を，A大 学の学生が受けているものと考えられる。

$\mathrm{B}$ 大学の学生は他大学の学生と比べてお菓子やファス トフードをよく摂取していた（表 5 (8)および9)）。2014 年 3 月の地点で, ケンタッキーフライドチキンの店舗数

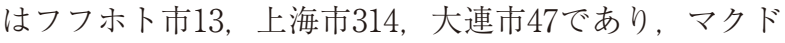
ナルドはフフホト市 7 , 上海市 164 ，大連市 31 である ${ }^{24)}$ $\mathrm{B}$ 大学でファストフード店の摂取頻度が高いのは, この 地域にファストフード店の数が多いことによるものと考 えられる。B大学では運動, クラブ, サークル活動など の課外活動, アルバイトなど, 学業以外の活動が他大学 よりも盛んであり（表6 (7)，8，(9)），インターネット もよく利用していた（表 6 (10)）。B 大学のある上海市は 中国最大の経済都市なので，そのことがこれらの結果に 反映されているものとも考えられる。 $\mathrm{B}$ 大学では，睡眠 時間 7 時間以上 8 時間未満の者が $56.0 \% ， 5$ 時間以上 6 時間未満の者が2.9\%であり，予想よりも睡眠時間がよ く確保されていた（表 6 (4)）。平成22年国民健康・栄養 調査 ${ }^{18)}$ によると，日本の20歳代女性に関して，睡眠時間 が 7 時間以上 8 時間未満の者の割合は $18.6 \%$, ここ 1 か 月間，眠れないことが頻繁にあった者は $14.6 \%$ である。 今回の調査では，眠れないことが頻繁にあった者の割合 は， 3 大学平均で $4.7 \%, B$ 大学で $2.9 \%$ であり, 睡眠の 質は良好であったといえる（表６５）。就寝時刻につい ては，その日のうちに寝る者の割合が 3 大学全体で $64.8 \%$, B 大学で68.0\%であり（表 6 (3)）, 日本の私立 
大学の学生 ${ }^{22)}$ ほど夜更かしをしていないことがわかった。 C 大学では，午後12時前に寝ている者の割合が $80.2 \%$, 睡眠時間が 7 時間以上の者の割合が70.4\%であり，睡眠 の質は良好であった（表 6 (3)，(4)，(5)）。この地域では 大学生の求人アルバイトがほとんどないとのことゆえ, アルバイトをしている者の割合が $4.9 \%$ と 3 大学で最も 少ないこと（表699）が，こうした好ましい結果をもた らす要因の一つであると考える。C大学ではインター ネットに 3 時間以上を費やす者が, B 大学と同様に半数 以上いた（表 6 (10)）。インターネットに費やす時間につ いては，4 時間以内， 5 時間以内， 5 時間以上という項 目を設定しておけば，大学間のより詳細な比較ができた ものと思われる。いずれにせよ C大学には長時間イン ターネットを利用している者が多い状況にあった。C大 学のある大連市の主要産業が電子情報・ソフトウェア関 連業であることや，C大学が情報系の学部であることが, このような結果に影響しているものと思われる。

夕食をほぼ毎日摂っている者は 3 大学全体で約半数と, 少なかった（表５（4)）。ここで, 夜食が遅い夕食ととら えられている可能性があることから, 夕食の摂取頻度と 夜食の摂取頻度をクロス集計してみた。その結果, (1)夕 食をほぼ毎日摂っている者の多くは夜食を週 $2 \sim 3$ 日 摂っている, (2)夕食をほとんど摂らない者は夜食もほと んど摂っていない, (3)夜食をほとんど毎日摂っている者 17 人のうちの 11 人は夕食もほぼ毎日摂っている, との結 果であった。このことから, 夜食を遅い夕食とはとらえ られていないものと思われた。平成 22 年の日本の国民健 康・栄養調査 ${ }^{18)}$ によると, 一人世帯において20歳代の女 性の夕食の欠食率は8.3\%であることから, 夕食に重き を置いている日本との間で大きな違いがみられる。

大半の学生の居住形態が寮であった。日本の大学生の 場合, 居住形態は, 自宅, 一人暮らし, 寮など多様であ $り^{25,26)}$ ，日本の大学生との間で違いがみられた。

ブレスローの「7つの健康習慣」 ${ }^{27)}$ に鑑みて，喫煙や 飲酒を常習的に嗜む者がいずれの大学でもほとんどいな いことは，生活習慣的に望ましいことである。睡眠時間 および就寝時刻についても日本の大学生よりも良好で あった。一方, 低体重の者の割合は約 3 割と多く, 朝食 の摂取率の割合は約 6 割と少なく，運動習慣のある者の 割合は約 2 割と少なく, インターネットを 3 時間以上し ている者は約半数と多い状況にあった。これらの結果を もたらした要因の一つが, 経済が急速に発展していく中 で, 小学校, 中学校, 高等学校での健康教育がまだ十分 に行われていないことにあるのではないかと考える。

\section{5. 要 約}

人口超大国である中国ではこれからの高齢社会が問題 となってくる。筆者らは, 大学生の生活習慣がその後の 彼らの健康状態に影響を及ぼすのではないかと考えてい る。そこで内モンゴルの A 大学, 上海の B 大学, 大連
の C 大学の女子学生の生活習慣を比較することにより, 大学生の生活習慣を把握することを目的としてアンケー 卜調査を行った。そして統計解析を行うことにより, 以 下のような結果を得た。

1 ）契煙や飲酒を常習的に嗜む者がいずれの大学でもほ とんどいないことは, 生活習慣的に望ましいことで あった。しかし, 低体重の者の割合およびインターネッ 卜を 3 時間以上している者の割合が高く, ならびに運 動習慣のある者の割合および朝食の摂取率が低いとい う問題点がみられた。

2) BMI が 18.5 未満の者は, A 大学 29 人 (19.3\%), B 大学 82 人 $(46.9 \%), \mathrm{C}$ 大学 22 人 $(27.2 \%)$ であり, 瘦せすぎの者の割合が B大学で顕著に多い状態にあっ た。

3 ) Rosenberg 自尊感情尺度の評定值は 3 大学平均で 29. $14 \pm 4.04$ であり，日本人学生よりも中国人学生の ほうが高い状態にあった。A大学ではこの大学を第一 志望とする者が有意に多く, B 大学では有意に少な かったが, 自尊感情尺度の評定值は $\mathrm{A}$ 大学が $\mathrm{B}$ 大学 に比べて有意に低かった。

4 ）運動習慣がある者の割合は 3 大学全体で89人(21.9\%) であり，A大学では $15 人(10.0 \%)$ で有意に少なく, B 大学では60人 (34.3\%) で有意に多かった。

5 ）クラブ, サークル活動などの課外活動をしている者 の割合は 3 大学全体で 218 人 $(53.7 \%)$ であり，A大 学では 62 人 $(41.3 \%)$ で有意に少なく, B大学では 112 人 (64.0\%) で有意に多かった。

6 ）アルバイトをしている者の割合は，3 大学全体で59 人 $(14.5 \%)$ であり, C大学では 4 人 $(4.9 \%)$ で最 も少なかった。

7 ） 3 大学ともに大半の者は寮に住み, 夕食の摂取頻度 が低く，日本の大学生との間に違いがみられた。

\section{謝辞}

中国語への翻訳およびアンケートをとっていただきま した上海電力学院, 王艶先生ならびに大連外国語大学, 劉爽先生に感謝申し上げます。

\section{文献}

1) International Monetary Fund: World Economic Outlook Database April 2015, http://www.imf.org/external/pubs/ft/ weo/2015/01/weodata/index.aspx

2) 内閣府: 平成 27 年版高齢社会白書 (概要版), http:// www8.cao.go.jp/kourei/whitepaper/w2015/gaiyou/27pdf_ indexg.html

3 ) United Nations: World Population Prospects: The 2015 Revision, http://esa.un.org/unpd/wpp/DataQuery

4 ）王逸飛：高齢化社会における中国公的年金制度の課題, 人間社会環境研究， 25，25-40（2013）

5 ) 中華人民共和国教育部発展規劃司編：中国教育統計年鑑 2012年版, 1-17 各級教育の総入学率, http://www.spc. 
jst.go.jp/statistics/edustats2012/index.html

6 ) Sakamaki R, Toyama K, Amamoto R, Liu CJ, Shinfuku N: Nutritional knowledge, food habits and health attitude of Chinese university students-a cross sectional study. Nutr. J., 4: 4 (2005)

7) Makino M, Hashizume M, Tsuboi K, Yasushi M, Dennerstein L: Comparative study of attitudes to eating between male and female students in the People's Republic of China. Eat Weight Disord., 11, 111-117 (2006)

8 ) Guo J, Whittemore R, He GP: Factors that influence health quotient in Chinese college undergraduates. J. Clin. Nurs., 19 145-155 (2010)

9 ) Wang D, Xing XH, Wu XB: Healthy lifestyles of university students in China and influential factors. Scientific World Journal, article ID 412950, 10 pages (2013)

10) Bi J, Huang Y, Xiao Y, Li F, Wang T, Chen J, Wu L, Liu Y, Luo R, Zhao X: Association of lifestyle factors and suboptimal health status: a cross-sectional study of Chinese students. BMJ Open, 4 (6), e005156 (2014)

11) 照屋博行：21世紀を展望する学校保健, 学校保健研究, 42, 465-469 (2001)

12）内蒙古自治区人民政府, http://www.nmg.gov.cn

13）中国上海, http://www.shanghai.gov.cn

14）遼寧省人民政府, http://www.ln.gov.cn

15）中華人民共和国国家統計局：中国統計年鑑２013年版, http://www.spc.jst.go.jp/statistics/stats2013/index.html

16）内田知宏, 上埜高志：Rosenberg 自尊感情尺度の信頼性 および妥当性の検討一Mimura \& Griffiths 訳の日本語版を 用いて一, 東北大学大学院教育学研究科研究年報, 58, 257266 (2010)

17）小田利勝：SPSSによる統計解析入門, プレアデス出版,
長野, p.212 (2012)

18）国立健康 ·栄養研究所：国民健康 ·栄養の現状一平成 22 年厚生労働省国民健康・栄養調査報告より一, 第一出版, 東京 (2013)

19) Lee S, Lee AM: Disordered eating in three communities of China: a comparative study of female high school students in Hong Kong, Shenzhen, and rural Hunan. Int. J. Eat. Disord., 27, 317-327 (2000)

20）厚生労働省：平成25年国民健康 - 栄養調査結果の概要, http://www.mhlw.go.jp/file/04-Houdouhappyou-10904750Kenkoukyoku-Gantaisakukenkouzoushinka/0000106403.pdf

21) Schmitt DP, Allik J: Simultaneous administration of the Rosenberg Self-Esteem Scale in 53 nations: exploring the universal and culture-specific features of global self-esteem. $J$. Pers. Soc. Psychol., 89, 623-642 (2005)

22）西尾恵里子, 劉爽, 太田成俊：日本と中国の大学生の生 活習慣と自尊感情の調査, 日本食生活学会誌，25，271-282 (2015)

23）白雪晴: 学校外教育の日中比較, 現代社会文化研究, 29, 55-72 (2004)

24）百度文庫：肯德基, 麦当労在中国店舗数分布統計, http://wenku.baidu.com/view/0c740e94360cbalaa811da42. $\mathrm{html}$

25）内閣府：食育推進室「大学生の食に関する実態・意識調 查報告書 (2009), http://www8.cao.go.jp/syokuiku/more/ research/pdf/syoku-report.pdf

26）根立恵子, 石井幸江, 米田泰子, 由比ヨシ子 : 女子大学 生の日常食に扔ける魚類と肉類の利用状況および利用にお よぼす要因, 日本調理科学会誌，45，215-222（2012）

27) Belloc NB, Breslow L: Relationship of physical health status and health practice. Prev. Med., 1, 409-421 (1972) 